\title{
Single center study of ESBL-related strains of Enterobacteriaceae collected from clinical specimens of infants with the congenital heart disease using multiplex PCR amplification
}

\author{
G. V. Filonenko', O. S. Talalaiev'1, D. L. Kyryk², N. O. Kovalenko ${ }^{1}$, \\ I. M. Skorohod ${ }^{1}$, A. O. Salamanina ${ }^{1}$ \\ ${ }^{1}$ Center for Pediatric Cardiology and Cardiac Surgery \\ 28/1, Chornovola Str. Kyiv, Ukraine, 01135 \\ ${ }^{2}$ P. L. Shupik National medical academy of post-graduate education \\ 9, Dorohozhytska Str., Kyiv, Ukraine, 04112 \\ baklabccc@ukr.net
}

\begin{abstract}
Aim. To study ESBL phenotypes, as well as to identify individual genotypes of $\beta$-lactamases and to study their prevalence among clinical strains of Enterobacteriaceae collected from children with congenital heart diseases. Methods. Clinical strains of Enterobacteriaceae were studied in order to determine their susceptibility to antibiotics, using an automated system, before genotyping resistance determinants using multiplex PCR. Results. During the period of the study, $10.9 \%$ of ESBL-positive isolates were found among clinical strains of Enterobacteriaceae. Most ESBL-producing strains (33.3\%) were Klebsiella pneumoniae. Most strains producing extended-spectrum $\beta$-lactamases were isolated from the respiratory tract and accounted for $83.3 \%$. Conclusions. An experimental study provided new data as regards the prevalence of ESBL-producing genetic resistance determinants within the Enterobacteriaceae family, and their role in the development of complications. For the first time in Ukraine, we performed genotyping Multiplex PCR-based genotyping tests of ESBLpositive isolates. The study showed diagnostic value of molecular biological methods in identifying resistance determinants of microorganisms.
\end{abstract}

Keyword s: antibiotic resistance, $\beta$-lactam antibiotics, Enterobacteriaceae, ESBL, PCR, genotyping

\section{Introduction}

Acquired antibiotic resistance of the Enterobacteriaceae represents globally escalating problem in treatment of healthcare-as- sociated infections. The rapid evolution of bacterial resistance among Enterobacteriaceae to the beta-lactam class of antibiotics has reached epidemic proportions [1]. The background component of this growing resistance

(C) 2017 G. V. Filonenko et al.; Published by the Institute of Molecular Biology and Genetics, NAS of Ukraine on behalf of Biopolymers and Cell. This is an Open Access article distributed under the terms of the Creative Commons Attribution License (http://creativecommons.org/licenses/by/4.0/), which permits unrestricted reuse, distribution, and reproduction in any medium, provided the original work is properly cited 
is the expression of enzymes known as extended-spectrum $\beta$-lactamases (ESBL) by a bacterial cell. These enzymes are generally defined as beta-lactamases and confer bacterial resistance to penicillins, first-, second-, third-generation cephalosporins and to aztreonam, but not the carbapenems and cephamycins [2].

Widespread use of these groups of antibiotics has led to the expansion of $\beta$-lactamaseencoding genes in Enterobacteriaceae like TEM, CTX-M, and SHV which can be encoded on mobile genetic elements, including plasmids and transposons that also often encrypt adventive resistance genes including multiple classes of antibiotics [3].

Risk factors for ESBL infection development are patient's age, prolonged in-hospital stay and previous stay at an intensive care unit (ICU) stay, prior use of antibiotics, and indwelling devices such as urinary catheters, central venous catheters, tracheostomy, and endotracheal tubes [4].

ESBL-related hospital infections are associated with negative outcomes for patients, resulting in prolonged hospital stay, increased hospitalization / inpatient costs, and increased morbidity rates [2]. The main driver of this increased morbidity is insufficient antibiotic therapy. So, early monitoring of groups of surgical patients who are at risk for infection by ESBL-producing bacteria is crucial for a choice of antibiotic treatment strategy and important point for infection spread control.

Modern data indicate a growing prevalence of ESBL's isolated from different patient groups globally [5-10]. However, neither single- nor multicenter studies have been conducted on ESBL-related hospital infections in
Ukraine. The resistance is determined by the expression of bla genes belonging to bla $\mathrm{TEM}_{\mathrm{TE}}$, bla $_{\mathrm{SHV}}$, and bla $\mathrm{C}_{\mathrm{CTX}-\mathrm{M}}$ genes family. To date, CTX-M enzymes are characterized as the most clinically important groups of ESBLs, which is followed by SHV- and TEM-derived ESBLs. The $b l a_{\mathrm{TEM}}, b l a_{\mathrm{SHV}}$, and $b l a_{\mathrm{CTX}-\mathrm{M}}$ genes are responsible for production of evolutionarily relative enzymes - TEM $\beta$-lactamases, SHV $\beta$-lactamases, and CTX-M $\beta$-lactamases, respectively. To date, there are about 100 derivatives of TEM-1 enzymes; 185 new $\beta$-lactamases of the TEM family have been reported worldwide, while only ninety-three variants are responsible for production of ESBLs. According to data reported recently, among one hundred seventy-two types of SHV family of enzymes, forty-five were represented as extended-spectrum beta-lactamases. The CTX-M family includes more than sixty enzymes (http: //www.eucast.org/clinical breakpoints).

Multiple molecular typing methods, including PCR-based assays, have been developed for detection and identification of the growing number of bla $\mathrm{TEM}_{\mathrm{TEM}}, \mathrm{bla}_{\mathrm{SHV}}$ and bla $\mathrm{CTX}_{\mathrm{CT}-\mathrm{M}}$ genes. Though, there is still limited scientific data on epidemiology of ESBL spread in the Ukraine. To the best of our knowledge, this is the first study on the molecular epidemiology and antimicrobial susceptibilities of ESBL-producing Enterobacteriaceae among surgical patients in Ukraine.

The purpose of this study was to explore feasibility of simultaneous identification of $b l a_{\mathrm{TEM}}, b l a_{\mathrm{SHV}}$ and $b l a_{\mathrm{CTX}-\mathrm{M}}$ genes by multiplex PCR detection in a series of clinical isolates of Enterobacteriaceae with previously characterized ESBL phenotype, to im- 
plement routing monitoring of ESBLproducing Enterobacteriaceae strains at the Ukrainian Children's Cardiac Center (Kyiv, Ukraine), to determine predominant genotypes among ESBL-producing Enterobacteriaceae strains.

\section{Materials and Methods}

All study strains were selected based on the screening tests for the detection of ESBL-type enzymes. The isolates were collected from clinical specimens of patients hospitalized at the Ukrainian Children's Cardiac Center (Kyiv, Ukraine) during the period from January to December, 2015. The isolates were recovered from various clinical specimens, mostly tracheal discharges, throat swabs, wounds, urine and blood. The majority of the collected strains were obtained during cardiac surgery in 704 patients representing different regions of Ukraine. The average age in the studies was $128 \pm 106.5$ days ( 0 days to 1 year) (Table 1 ).

The ESBL phenotype of the bacterial strains was determined by the VITEK 2 GN cards and the automated identification system (bioMerieux, France) in accordance with internal SOPs and manufacturer's protocols.

\section{Testing of antibiotic susceptibility and ESBL determination}

Susceptibility of clinical isolates to $\beta$-lactams (ampicillin, cefazolin, cefuroxime, cefepime, ceftriaxone, imipenem, and meropenem) and to ciprofloxacin, amikacin, ofloxacin, levofloxacin, tobramycin, and trimethoprim / sulfamethoxazole was tested by using AST-N076 cards and the automated VITEK 2 system. Susceptibility was interpreted according to the
European Committee on Antimicrobial Susceptibility Testing (EUCAST) recommendations (http://www.eucast.org/clinicalbreakpoints). Thirty Enterobacteriaceae strains including twenty-two strains of $K$. pneumoniae, four strains of E.coli, and four strains of other Enterobacteriaceae from hospitalized patients were found to be ESBL producers. The presence of ESBL phenotype was confirmed by VITEK 2 automated system.

\section{DNA isolation}

Purified DNA from overnight bacterial cultures was isolated using the QIAGEN DNeasy Blood and Tissue Kit (Catalog\# 69504) and NucleoSpin ${ }^{\circledR}$ Blood QuickPure kit (MACHEREY NAGEL, Germany). Qualitative analysis of DNA was performed by electrophoresis in $1 \%$ agarose gel with $0.5 \%$ TBE buffer (Tris-Borate-EDTA).

\section{Multiplex PCR amplification}

Multiplex PCR-based genotyping tests were conducted on thirty ESBL-positive isolates (Table 1) including twenty-two strains of $K$. pneumoniae, four strains of E.coli, and four strains of other Enterobacteriaceae (Enterobacter cloacae, Serratia marcescens and Klebsiella oxytoca).

For genotyping tests, we used sequence primers-pair and technique of multiplex PCR, with some modifications, described previously [11].

Primer-pair sequences (bla-SHV.SE/AS; TEM-164.SE and TEM-165.AS; universal CTX-M-U1/U2) used in the multiplex PCR and assay PCR amplicon sizes are given in Table 2 . The reaction mixtures contained $1 \times$ PCR buffer, $200 \mu \mathrm{M}$ dNTP, 0.5 unit of Taq 
Table 1. Overview of all strains, identified bla genes, and resistance phenotypes

\begin{tabular}{|c|c|c|c|c|c|c|c|c|c|c|c|}
\hline \multirow{2}{*}{$\begin{array}{l}\text { Name of } \\
\text { the strain }\end{array}$} & \multirow{2}{*}{ Origin } & \multirow{2}{*}{ Region } & \multicolumn{3}{|c|}{ Multiplex PCR } & \multirow{2}{*}{\multicolumn{5}{|c|}{$\begin{array}{l}\text { Resistance phenotype to non- } \beta \text {-lactam } \\
\text { antibiotics }\end{array}$}} & \multirow{2}{*}{$\begin{array}{c}\text { Active } \beta \text {-lactam } \\
\text { antibiotics }\end{array}$} \\
\hline & & & $b l a_{\mathrm{CTX}-\mathrm{M}}$ & $b l a_{\mathrm{TEM}}$ & $b l a_{\mathrm{SHV}}$ & & & & & & \\
\hline 1. $\mathrm{Kl}$ & $\mathrm{R}$ & $\mathrm{Kv}$ & & + & + & $\mathrm{AMK}^{\mathrm{R}}$ & $\mathrm{TOB}^{\mathrm{R}}$ & $\mathrm{CIP}^{\mathrm{R}}$ & OFX $^{R}$ & & \\
\hline 2. $\mathrm{Kl}$ & $\mathrm{w}$ & $\mathrm{Kv}$ & + & + & & & & & $\mathrm{OFX}^{\mathrm{R}}$ & $\mathrm{SXT}^{\mathrm{R}}$ & MEM,IMP \\
\hline 3. $\mathrm{Kl}$ & $\mathrm{R}$ & Zap & + & & + & & & & & & MEM,IMP \\
\hline 4. $\mathrm{Kl}$ & $\mathrm{R}$ & $\mathrm{Kv}$ & + & & + & & & & & $\mathrm{SXT}^{\mathrm{R}}$ & MEM,IMP \\
\hline 5. $\mathrm{Kl}$ & $\mathrm{R}$ & $\mathrm{Lv}$ & + & + & & & & & & & MEM,IMP \\
\hline 6. $\mathrm{Kl}$ & $\mathrm{R}$ & Vol & + & + & + & $\mathrm{AMK}^{\mathrm{R}}$ & $\mathrm{TOB}^{\mathrm{R}}$ & & & $\mathrm{SXT}^{\mathrm{R}}$ & MEM,IMP \\
\hline 7. $\mathrm{Kl}$ & $\mathrm{R}$ & $\mathrm{Zh}$ & & + & + & $\mathrm{AMK}^{\mathrm{R}}$ & $\mathrm{TOB}^{\mathrm{R}}$ & $\mathrm{CIP}^{\mathrm{R}}$ & $\mathrm{OFX}^{\mathrm{R}}$ & & \\
\hline 8. $\mathrm{Kl}$ & bl & $\mathrm{Zh}$ & & + & + & $\mathrm{AMK}^{\mathrm{R}}$ & $\mathrm{TOB}^{\mathrm{R}}$ & $\mathrm{CIP}^{\mathrm{R}}$ & $\mathrm{OFX}^{\mathrm{R}}$ & & \\
\hline 9. $\mathrm{Kl}$ & $\mathrm{R}$ & Don & + & & & & & & & & MEM,IMP,FEP,СТM \\
\hline 10. K1 & $\mathrm{R}$ & Vol & + & & & $\mathrm{AMK}^{\mathrm{R}}$ & $\mathrm{TOB}^{\mathrm{R}}$ & & & & MEM,IMP \\
\hline 11. Kl & $\mathrm{R}$ & $\mathrm{K}$ & & + & + & $\mathrm{AMK}^{\mathrm{R}}$ & $\mathrm{TOB}^{\mathrm{R}}$ & $\mathrm{CIP}^{\mathrm{R}}$ & OFX $^{\mathrm{R}}$ & $\mathrm{SXT}^{\mathrm{R}}$ & \\
\hline 12. $\mathrm{Kl}$ & $\mathrm{R}$ & Iv & & + & + & $\mathrm{AMK}^{\mathrm{R}}$ & $\mathrm{TOB}^{\mathrm{R}}$ & & & & MEM,IMP \\
\hline 13. K1 & bl & Dn & & + & + & $\mathrm{AMK}^{\mathrm{R}}$ & $\mathrm{TOB}^{\mathrm{R}}$ & $\mathrm{CIP}^{\mathrm{R}}$ & OFX $^{\mathrm{R}}$ & $\mathrm{SXT}^{\mathrm{R}}$ & \\
\hline 14. Kl & ur & Od & & + & + & $\mathrm{AMK}^{\mathrm{R}}$ & $\mathrm{TOB}^{\mathrm{R}}$ & CIPR & $\mathrm{OFX}^{\mathrm{R}}$ & $\mathrm{SXT}^{\mathrm{R}}$ & MEM,IMP \\
\hline 15. Kl & oth & Vol & & + & & $\mathrm{AMK}^{\mathrm{R}}$ & $\mathrm{TOB}^{\mathrm{R}}$ & & & & MEM,IMP \\
\hline 16. K1 & $\mathrm{R}$ & Vin & + & + & + & & & & & & \\
\hline 17. K1 & $\mathrm{R}$ & Vin & + & + & & & & & & & MEM,IMP \\
\hline 18. K1 & $\mathrm{R}$ & Vol & & + & & $\mathrm{AMK}^{\mathrm{R}}$ & $\mathrm{TOB}^{\mathrm{R}}$ & & & & MEM,IMP \\
\hline 19. Kl & $\mathrm{R}$ & $\mathrm{Kv}$ & + & & & & & $\mathrm{CIP}^{\mathrm{R}}$ & OFX $^{\mathrm{R}}$ & & MEM,IMP \\
\hline 20. K1 & $\mathrm{R}$ & Don & & + & & $\mathrm{AMK}^{\mathrm{R}}$ & $\mathrm{TOB}^{\mathrm{R}}$ & & & & MEM,IMP \\
\hline 21. K1 & $\mathrm{R}$ & $\mathrm{Kv}$ & & + & + & & & & & & MEM,IMP \\
\hline 22. Kl & $\mathrm{R}$ & Vin & + & + & & & & & & & MEM,IMP \\
\hline 23. K1.o & $\mathrm{R}$ & $\mathrm{Zh}$ & & + & + & $\mathrm{AMK}^{\mathrm{R}}$ & $\mathrm{TOB}^{\mathrm{R}}$ & $\mathrm{CIP}^{\mathrm{R}}$ & $\mathrm{OFX}^{\mathrm{R}}$ & & \\
\hline 24. E & $\mathrm{R}$ & $\mathrm{Kv}$ & & + & & & & $\mathrm{CIP}^{\mathrm{R}}$ & & & MEM,IMP \\
\hline 25. E & $\mathrm{R}$ & $\mathrm{Lv}$ & & + & + & & & CIPR & & & MEM,IMP \\
\hline 26. E & $\mathrm{R}$ & $\mathrm{Kv}$ & + & & & & & & & & MEM,IMP \\
\hline 27. E & $\mathrm{R}$ & Od & & + & & & & $\mathrm{CIP}^{\mathrm{R}}$ & $\mathrm{OFX}^{\mathrm{R}}$ & & MEM,IMP \\
\hline 28. En & $\mathrm{R}$ & $\mathrm{Lv}$ & & + & + & & & & & & MEM,IMP \\
\hline 29. S & $\mathrm{R}$ & $\mathrm{Zh}$ & + & & & & & & & & MEM,IMP \\
\hline 30. $\mathrm{S}$ & $\mathrm{R}$ & $\mathrm{Kv}$ & & & & & & & & & MEM,IMP,FEP,CTM \\
\hline
\end{tabular}

Strains: Kl: Klebsiella pneumoniae, Kl.o: Klebsiella oxytoca; E: E. coli; En: Enterobacter cloacae; S: Serratia marcescens, Antibiotics: AMK-amikacin, TOB-tobramycin, CIP-ciprofloxacin, OFX- ofloxacin, SXT-trimethoprim / sulfamethoxazole, MEM-meropenem, IMP-imipenem, FEP-cefepime, CTM-cefuroxime;

Origin: R - respiratory, bl - blood, ur - urine, w - wound, oth - other;

Region: Kv - Kyiv, Lv - Lviv, Od - Odessa, Don - Donetsk, Dn - Dnipro, Zh - Zhytomyr, Vol - Volyn, Vin - Vinnytsia, Zap Zaporizhia, Iv - Ivano-Frankivsk 
polymerase (Roche, Germany), $10 \mathrm{pmol} / \mu \mathrm{l}$ of each gene-specific primer and $1 \mu 1$ of DNA solution in a final volume of $10 \mu \mathrm{l}$. PCR amplification conditions were as follows: initial denaturation step at $95{ }^{\circ} \mathrm{C}$ for $15 \mathrm{~min}$; $30 \mathrm{cy}$ cles of denaturation at $94{ }^{\circ} \mathrm{C}$ for $30 \mathrm{~s}$, annealing at $60{ }^{\circ} \mathrm{C}$ for $30 \mathrm{~s}$, extension at $72{ }^{\circ} \mathrm{C}$ for $2 \mathrm{~min}$, followed by a final extension step at $72{ }^{\circ} \mathrm{C}$ for $10 \mathrm{~min}$.

PCR amplicons were separated electrophoretically in $2 \%(\mathrm{w} / \mathrm{w})$ agarose gel containing $0.5 \mu \mathrm{g} / \mathrm{ml}$ ethidium bromide (Sigma Aldrich, USA) and $0.5 \%$ TBE buffer and visualized with «DOC-Print VX2» (Vilber Lourmat) system.

\section{Results and Discussion}

In this study, we examined the prevalence of ESBL producing Enterobacteriaceae and carried out molecular characterization and antimicrobial susceptibility testing of clinical samples from patients during their admission to the cardiac hospital.

ESBL-producing Enterobacteriaceae were obtained from clinical specimens of patients representing different regions of Ukraine (30.0\% were from Kyiv, $13.3 \%$ were from Zhytomyr, $13.3 \%$ were from Volyn, $10.0 \%$ were from Lviv, $10.0 \%$ were from Vinnytsa, $6.6 \%$ were from Odessa, $6.6 \%$ were from
Donetsk, $3.3 \%$ were from Ivano-Frankivsk, $3.3 \%$ were from Zaporizhia and $3.3 \%$ were from Dnipro) hospitalized at the Ukrainian Children's Cardiac Center (Kyiv, Ukraine).

During the study period, total of $30(10.9 \%)$ ESBL-producing Enterobacteriaceae were isolated. The demographic profile of the studied population was summarized. It shows that $56.6 \%(n=17)$ of ESBL-positive samples were collected from male patients and $43.3 \%$ $(\mathrm{n}=13)$ of samples were from female patients (Table 1). Among the isolates, K. pneumoniae (33.3 \%, $\mathrm{n}=22)$ was prevalent ESBLproducing bacteria, ESBL-phenotype of $E$. coli accounted for $13.3 \%(n=4)$, and other ESBLproducing Enterobacteriaceae accounted for $13.3 \%(n=4)$. These pathogens were isolated from a variety of clinical samples, respiratory system $-83.3 \%(\mathrm{n}=25)$, blood $-6.6 \%$ $(\mathrm{n}=2)$, and others $-10.0 \%(\mathrm{n}=3)$.

In our study, the main ESBL producers were found to be K. pneumoniae and E. coli and other species, which is consistent with previously published results $[9,14,15]$, overall part of ESBL-producing pathogens among Enterobacteriaceae strains was substantially lower $(10.9 \%)$ than that reported in other studies in other geographical regions $[14,15]$ and higher than reported in other hospital-associated infection studies $[11,13]$. The majority of

Table 2. Primers used in multiplex PCR amplification

\begin{tabular}{|l|l|c|c|}
\hline \multicolumn{1}{|c|}{ Primer name } & \multicolumn{1}{|c|}{ Primer sequence (5'-3') } & Amplicon size in bp. & Origin of references \\
\hline bla-SHV.SE & atgcgttatattcgcetgtg & 747 & {$[11,12]$} \\
bla-SHV.AS & tgctttgttattcgggccaa & 445 & {$[11]$} \\
TEM-164.SE & tcgecgcatacactattctcagaatga & & \\
TEM-165.AS & acgctcaccggctccagatttat & 593 & {$[11,13]$} \\
CTX-M-U1 & atgtgcagyaccagtaargtkatggc & tgggtraartargtsaccagaaycagcgg & \\
CTX-M-U2 & \multicolumn{2}{|l}{} \\
\hline
\end{tabular}


these infections were due to $E$. coli rather than Klebsiella pneumoniae, as described in the non-transplant literature in many cases and as was observed in our study. However, during screening of 1065 patients at the UCLA Medical Center who had undergone heart or lung transplantation between 1996 and 2010, the incidence of ESBL-related infections in these groups appeared to be $2.2 \%, 5.5 \%$, and $10.7 \%$ of patients, respectively [13]. It can be explained by methodological differences in the measured prevalence levels, difference in age groups of patients and time-depended distribution of resistance.

In this study, the respiratory tract was the major source of ESBL-producing isolates, followed by the blood and other sampling media. Similar findings have previously been reported for the ICUs at hospitals in Mexico, India and Qatar where the major source of ESBLproducing isolates were the respiratory tract and blood $[9,16,17]$. However, in other geographical regions, urine and blood were reported as the major source of ESBL-producing bacteria $[6,12]$.

The antibiotic susceptibilities of ESBLproducers are presented in Table 1. Among $K$. pneumonia strains expressing ESBL activity, high levels of resistance to ampicillin (100\%), cefazolin $(100 \%)$, ceftriaxone $(100 \%)$, cefuroxime $(100 \%)$, and cefepime $(95.7 \%)$ were observed. Tested strains of $K$. pneumoniae were susceptible to imipenem (69.6\%) and meropenem (69.6 \%). All E. coli ESBLpositive strains were resistant to ampicillin (intrinsic resistance), cefazolin, cefuroxime, ceftriaxone, and cefepime. Furthermore, ESBL-positive E. coli strains were highly susceptible to meropenem (100\%) and imipenem (100\%). Additionally, other Enterobacteriaceae ESBL-positive strains were completely resistant to ampicillin, cefazolin, and cefuroxime.

Table 3. Susceptibility of Enterobactetiacae ESBL-positive strains $(\mathbf{n}=\mathbf{3 0})$

\begin{tabular}{|c|c|c|c|c|c|c|c|c|c|}
\hline \multirow{2}{*}{ Antibiotic } & \multicolumn{3}{|c|}{ Klebsiella pneumonia } & \multicolumn{3}{|c|}{ E. coli } & \multicolumn{3}{|c|}{ Other Enterobacteriacea } \\
\hline & $\mathrm{R}$ & $\mathrm{I}$ & $\mathrm{S}$ & $\mathrm{R}$ & $\mathrm{I}$ & $\mathrm{S}$ & $\mathrm{R}$ & $\mathrm{I}$ & $\mathrm{S}$ \\
\hline AMP ampicillin & 100 & & 0 & 100 & & 0 & 100 & & 0 \\
\hline CZO cefazolin & 100 & & 0 & 100 & & 0 & 100 & & 0 \\
\hline CXM cefuroxime & 100 & & 0 & 100 & & 0 & 100 & & 0 \\
\hline CRO ceftriaxone & 100 & & 0 & 100 & & 0 & 50 & & 50 \\
\hline FEP cefepime & 95,7 & 4,3 & 0 & 100 & & 0 & 50 & & 50 \\
\hline IMP imipenem & 30,4 & & 69,6 & 0 & & 100 & 0 & & 100 \\
\hline MEM meropenem & 30,4 & & 69,6 & 0 & & 100 & 0 & & 100 \\
\hline AMK amikacin & 56,5 & 8,7 & 34,8 & 0 & & 100 & 25 & & 75 \\
\hline TOB tobramycin & 56,5 & 8,7 & 34,8 & 0 & & 100 & 25 & & 75 \\
\hline CIP ciprofloxacin & 34,8 & 13 & 52,2 & 75 & & 25 & 25 & & 75 \\
\hline LVX levofloxacin & 34,8 & 4,3 & 60,9 & 50 & & 50 & 25 & & 75 \\
\hline OFX ofloxacin & 39,1 & & 60,9 & 25 & & 75 & 25 & & 75 \\
\hline $\begin{array}{l}\text { SXT trimethoprim/ } \\
\text { sulfametoxazole }\end{array}$ & 34,8 & 4,3 & 60,9 & 100 & & 0 & 0 & & 100 \\
\hline
\end{tabular}


High activity against other Enterobacteriaceae was shown by ceftriaxone (50\%), cefepime (50\%), imipenem (100\%), and meropenem (100\%) (Table 3).

Our epidemiological data show a dramatic increase in antimicrobial resistance. Additionally, more and more studies show continuous evolution of resistance to $\beta$-lactams and other groups of antibiotics in the bacteria of the Enterobacteriaceae family [6-16, 18, 19].

The constant increase of simultaneous resistance to various classes of antibiotics significantly reduces the possibility of therapeutic treatment of infections caused by ESBLproducers $[6-10,12,14,15,18]$. That prompted us to analyze the level of resistance among ESBL-positive tested strains.

ESBL-producers revealed high resistance to antibiotic groups other than $\beta$-lactams. The results of our study are in line with some global reports $[17,20]$. Our analysis showed a significant degree of ESBL-positive $K$. pneumoniae resistance to such antibiotics as ofloxacine, levofloxacin, trimethoprim/sulfamethoxazole and ciprofloxacin. The percentages of resistant strains were, respectively, $60.9 \%, 60.9 \%, 60.9 \%$, and $52.2 \%$. E. coli ESBL-positive strains appeared to be resistant to such antibiotics as ciprofloxacin (75\%), levofloxacin $(25 \%)$, and ofloxacine $(25 \%)$ (Table 3).

ESBL-positive strains showing simultaneous resistance to $\beta$-lactamases and antibiotics of other groups are defined as multidrug-resistant strains $[1,2]$. Global spread of multidrugresistant strains as an etiological factor of infections is described in numerous reports [121]. Characteristic location of genes responsible for resistance is the reason contributing to the prevalence of this phenomenon. Genes encoding $\beta$-lactamases are often located in mobile genetic elements such as plasmids, allowing horizontal transfer of these genes between bacteria of Enterobacteriaceae species and non-fermenting bacteria [3].

In Enterobacteriaceae, resistant genes responsible for resistance to different groups of antibiotics are often located on the same plasmids in a close neighborhood and, thus can be transmitted at the same time to other bacteria [21].

The ESBL-producing pathogens identified by phenotypic methods were also analyzed by using PCR methods. Of 30 ESBL isolates, $6.6 \%$ harbored multiple bla genes simultaneously and the prevalence of $b l a_{\mathrm{TEM}}$ was as high as $70.0 \%$, followed by $b l a_{\mathrm{SHV}}$ at $46.6 \%$, and $b l a_{\text {CTX-M }}$ at $46.6 \%$. The majority of the TEMpositive isolates were $K$. pneumoniae $(81.8 \%)$, E. coli (50.0\%), and other Enterobacteriaceae, (33.1\%); however, all CTX-M and SHV positive isolates were $K$. pneumoniae (50.0\% and $59.0 \%$ respectively). Furthermore, all three bla genes (TEM, SHV, and CTX-M) were detected in only $9.0 \%$ of $K$. pneumoniae isolates, while two genes (SHV/CTX-M) were present in $9.0 \%$ of $K$. pneumoniae, with TEM/ CTX-M being present in $22.5 \%$ of $K$. pneumoniae and TEM/SHV being detected in $45.5 \%$ of $K$. pneumoniae, and $33.3 \%$ in other Enterobacteriaceae isolates (Table 1, Fig. 1).

\section{Conclusions}

Compared with previous data from other geographical regions, our study shows relatively low prevalence (10.9 \%) of ESBL-producing Enterobacteriaceae. Though lower than in 


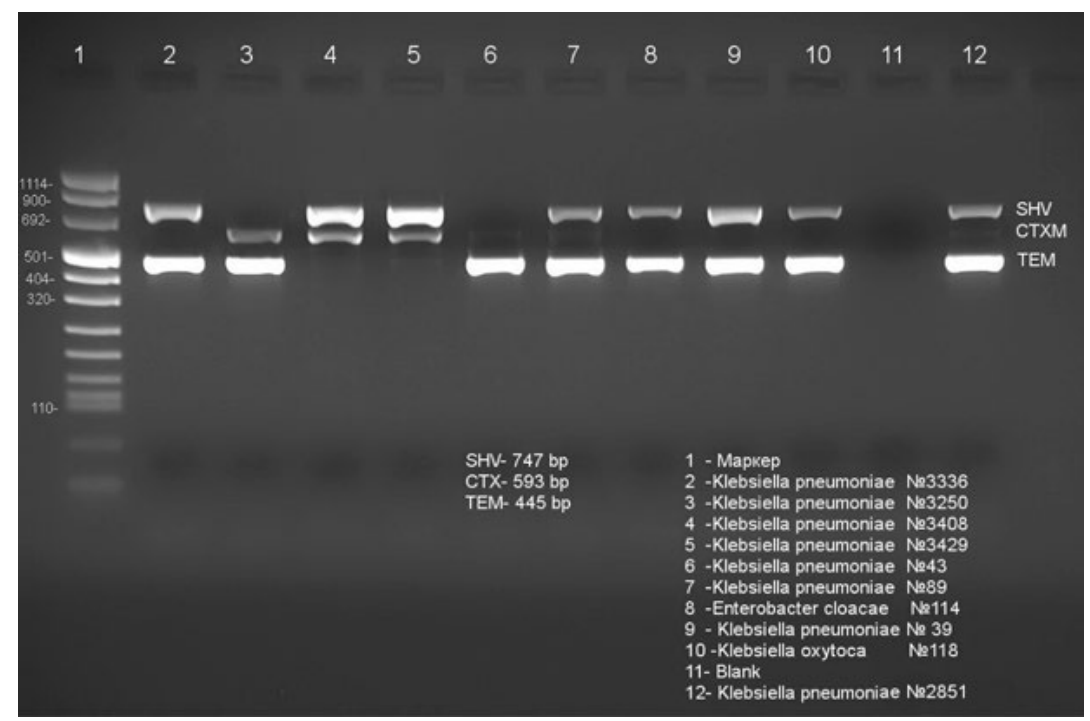

Fig. 1. Electropherogram analysis of multiplex PCR amplified products.

1 - DNA molecular weight marker; 2-7, 9 - Klebsiella pneumoniae; 8 Enterobacter cloacae; 10 - Klebsiella oxytoca; 11 - blank, 12 - control strain- Klebsiella pneumonia ATCC 700603. other countries and regions, our results suggest that there is sufficient global infection burden to warrant public health interventions. Notably, majority of isolates were multi-drug resistant and belonged to TEM plasmid-type. The emergence of TEM producing Enterobacteriaceae isolates is of major concern and necessitates further control and research in this area. As meropenem shows good activity against these ESBL producers, it should be restricted for managing patients with suspected Gramnegative bacterial infections with ESBL production. Additionally, antimicrobial control and early detection by active surveillance in combination with effective infection monitoring programs and methods are key steps for reducing or controlling the spread of ESBLpositive hospital-acquired infections in Ukraine.

\section{Conflict of Interests}

The authors declare that there is no conflict of interests regarding the publication of this paper.

\section{REFERENCES}

1. Sievert DM, Ricks P, Edwards JR, Schneider A, Patel J, Srinivasan A, Kallen A, Limbago B, Fridkin S; National Healthcare Safety Network (NHSN) Team and Participating NHSN Facilities. Antimicrobial-resistant pathogens associated with healthcare-associated infections: summary of data reported to the National Healthcare Safety Network at the Centers for Disease Control and Prevention, 2009-2010. Infect Control Hosp Epidemiol. 2013;34(1):1-14.

2. Paterson DL, Bonomo RA. Extended-spectrum betalactamases: a clinical update. Clin Microbiol Rev. 2005;18(4):657-86.

3. Bush K, Fisher JF. Epidemiological expansion, structural studies, and clinical challenges of new $\beta$-lactamases from gram-negative bacteria. Annu Rev Microbiol. 2011;65:455-78.

4. Stürenburg E, Mack D. Extended-spectrum betalactamases: implications for the clinical microbiology laboratory, therapy, and infection control. $J$ Infect. $2003 ; 47(4): 273-95$.

5. Ben-Ami R, Rodríguez-Baño J, Arslan H, Pitout JD, Quentin C, Calbo ES, Azap OK, Arpin C, Pascual A, Livermore DM, Garau J, Carmeli Y. A multinational survey of risk factors for infection with extended-spectrum beta-lactamase-producing entero- 
bacteriaceae in nonhospitalized patients. Clin Infect Dis. 2009;49(5):682-90.

6. Doi Y, Park YS, Rivera JI, Adams-Haduch JM, Hingwe A, Sordillo EM, Lewis JS 2nd, Howard WJ, Johnson LE, Polsky B, Jorgensen JH, Richter SS, Shutt KA, Paterson DL. Community-associated extended-spectrum $\beta$-lactamase-producing Escherichia coli infection in the United States. Clin Infect Dis. 2013;56(5):641-8.

7. Moor CT, Roberts SA, Simmons G, Briggs S, Morris AJ, Smith J, Heffernan $H$. Extended-spectrum beta-lactamase (ESBL)-producing enterobacteria: factors associated with infection in the community setting, Auckland, New Zealand. J Hosp Infect. 2008;68(4):355-62.

8. Ojdana D, Sacha P, Wieczorek P, Czaban S, Michalska A, Jaworowska J, Jurczak A, Poniatowski B, Tryniszewska E. The Occurrence ofblaCTXM,blaSHV, andblaTEMGenes in ExtendedSpectrum $\beta$-Lactamase-Positive Strains ofKlebsiella pneumoniae,Escherichia coli, andProteus mirabilisin Poland. Int J Antibiot. 2014;2014:1-7.

9. Sid Ahmed MA, Bansal D, Acharya A, Elmi AA, Hamid JM, Sid Ahmed AM, Chandra P, Ibrahim E, Sultan AA, Doiphode S, Bilal NE, Deshmukh A. Antimicrobial susceptibility and molecular epidemiology of extended-spectrum beta-lactamase-producing Enterobacteriaceae from intensive care units at Hamad Medical Corporation, Qatar. Antimicrob Resist Infect Control. 2016;5:4.

10. Al-Jassera AM. Extended-spectrum beta-lactamases (ESBLs): a global problem. Kuwait Medical Journal. 2006; 38(3): 171-85.

11. Monstein HJ, Ostholm-Balkhed A, Nilsson MV, Nilsson M, Dornbusch K, Nilsson LE. Multiplex PCR amplification assay for the detection of blaSHV, blaTEM and blaCTX-M genes in Enterobacteriaceae. APMIS. 2007;115(12):1400-8.

12. Paterson DL, Hujer KM, Hujer AM, Yeiser B, Bonomo MD, Rice LB, Bonomo RA; International Klebsiella Study Group. Extended-spectrum beta-lactamases in Klebsiella pneumoniae bloodstream isolates from seven countries: dominance and widespread prevalence of SHV- and CTX-M-type beta- lactamases. Antimicrob Agents Chemother. 2003; 47(11):3554-60.

13. Boyd DA, Tyler S, Christianson S, McGeer A, Muller MP, Willey BM, Bryce E, Gardam M, Nordmann $P$, Mulvey MR. Complete nucleotide sequence of a 92-kilobase plasmid harboring the CTX-M-15 extended-spectrum beta-lactamase involved in an outbreak in long-term-care facilities in Toronto, Canada. Antimicrob Agents Chemother. 2004; 48(10):3758-64.

14. Shah AA, Hasan F, Ahmed S, Hameed A. Characteristics, epidemiology and clinical importance of emerging strains of Gram-negative bacilli producing extended-spectrum beta-lactamases. Res Microbiol. 200;155(6):409-21.

15. Guzmán-Blanco M, Labarca JA, Villegas MV, Gotuzzo E; Latin America Working Group on Bacterial Resistance. Extended spectrum $\beta$-lactamase producers among nosocomial Enterobacteriaceae in Latin America. Braz J Infect Dis. 2014;18(4):42133.

16. Patel J, Everly M, Chang D, Kittleson M, Reed E, Kobashigawa J. Reduction of alloantibodies via proteasome inhibition in cardiac transplantation. $J$ Heart Lung Transplant. 2011;30(12):1320-6.

17. Martins IS, Moreira BM, Riley LW, SantoroLopes $G$. Outbreak of extended-spectrum beta-lactamase-producing Klebsiella pneumoniae infection among renal transplant recipients. $J$ Hosp Infect. 2006;64(3):305-8.

18. Zowawi HM, Balkhy HH, Walsh TR, Paterson DL. $\beta$-Lactamase production in key gram-negative pathogen isolates from the Arabian Peninsula. Clin Microbiol Rev. 2013;26(3):361-80.

19. Garza-González E, Mendoza Ibarra SI, LlacaDíaz JM, Gonzalez GM. Molecular characterization and antimicrobial susceptibility of extended-spectrum \{beta\}-lactamase-producing Enterobacteriaceae isolates at a tertiary-care centre in Monterrey, Mexico. J Med Microbiol. 2011;60(Pt 1):84-90.

20. Sharma $M$, Pathak S, Srivastava P. Prevalence and antibiogram of Extended Spectrum $\beta$-Lactamase (ESBL) producing Gram negative bacilli and further molecular characterization of ESBL producing Esch- 
Single center study of ESBL-related strains of Enterobacteriaceae from infants with congenital heart disease

erichia coli and Klebsiella spp. J Clin Diagn Res. 2013;7(10):2173-7.

21. Giamarellou H, Poulakou G. Multidrug-resistant Gram-negative infections: what are the treatment options? Drugs. 2009;69(14):1879-901.

Дослідження штамів Enterobacteriaceae, що продукують БЛРС, і виділені з клінічних зразків у дітей з вродженими вадами серця 3 допомогою мультиплексной ПЛР.

Г. В. Філоненко, О. С. Талалаєв, Д. Л. Кирик, Н. О. Коваленко, І. М. Скороход, А. О. Саламаніна

Мета. Вивчити фенотипи БЛРС і ідентифікацію обраних генотипів $\beta$-лактамаз і частоту їх поширення серед клінічних штамів Enterobacteriaceae, виділених у дітей з вродженими вадами серця. Методи. Проведено дослідження клінічних штамів Enterobacteriaceae 3 метою визначення їх чутливості до антибіотиків 3 використанням автоматичної системи і $з$ подальшим генотипуванням детермінант резистентності методом мультиплексной ПЛР. Результати. За досліджуваний період серед клінічних штамів Enterobacteriaceae було виявлено 10,9 \% БЛРС-позитивних ізолятів. Переважну більшість штамів, продуцентів БЛРС - 33,3 \% склали Klebsiella pneumoniae. Найбільша кількість штамів-продуцентів $\beta$-лактамаз розширеного спектру дії було виділено з респіраторного тракту і склало 83,3 \%. Висновки. Експериментальне дослідження дало нові дані про поширення генетичних детермінант резистентності родини Enterobacteriaceae, що продукують БЛРС і їхню роль в розвитку ускладнень. Робота продемонструвала діагностичну цінність молекулярнобіологічних методів для ідентифікації детермінант резистентності у мікроорганізмів.

К л юч ов і с лов а: Антибіотикорезистентність; $\beta$-лактамні антибіотики; ентеробактерії; БЛРС; ПЛР; генотипування
Исследование штаммов Enterobacteriaceae, которые продуцируют БЛРС, выделеных из клинических образцов у детей с врождёнными пороками сердца с помощью мультиплексной ПЦР

Г. В. Филоненко, А. С. Талалаев, Д. Л. Кирик, Н. О. Коваленко, И. Н. Скороход,

А. А. Саламанина

Цель. Изучить фенотипи БЛРС и идентификацию избранных генотипов $\beta$-лактамаз и частоту их распространения среди клинических штаммов Enterobacteriaceae, выделенных у детей с врождёнными пороками сердца. Методы. Проведены исследования клинических штаммов Enterobacteriaceae с целью определения их чувствительности к антибиотикам с использованием автоматической системы и с последующим генотипированием детерминант резистентности методом мультиплексной ПЦР. Результаты. За исследуемый период среди клинических штаммов Enterobacteriaceae было выявлено 10,9 \% БЛРС-положительных изолятов. Превалирующее большинство штаммов, продуцентов БЛРС - 33,3 \% составили Klebsiella pneumoniae. Наибольшее количество штаммов-продуцентов $\beta$-лактамаз расширенного спектра действия было выделено с респираторного тракта и составило 83,3 \%. Выводы. Экспериментальное исследование дало новые данные о распространении генетических детерминант резистентности в семействе Enterobacteriaceae, которые продуцируют БЛРС и их места в развитии осложнений. Работа продемонстрировала диагностическую ценность молекулярно-биологических методов для идентификации детерминант резистентности у микроорганизмов.

К л юч е в ы е с л о в а: Антибиотикорезистентность, $\beta$-лактамные антибиотики, энтеробактерии, БЛРС, ПЦР, генотипирование.

Received 02.11.2017 